\title{
Akut Tolüen Maruziyetinin Tavşan Beyin Korteksinde Yol Açtığı Toksik Etkiler
}

\author{
Mustafa Çiçek ${ }^{1}$, Turgay Şişman ${ }^{2}$ \\ ${ }^{1}$ Kahramanmaraş Sütçü İmam Üniversitesi Tıp Fakültesi Anatomi AD. \\ ${ }^{2}$ Atatürk Üniversitesi Fen Fakültesi Biyoloji AD.
}

Geliş Tarihi / Received: 02.11.2016, Kabul Tarihi / Accepted: 31.12.2016

\begin{abstract}
Özet: Bu çalışmada yüksek dozda tolüenin tavşan beyin korteksi üzerine akut dönemdeki histopatolojik ve biyokimyasal etkilerinin araştırılması amaçlandı. On yedi adet Yeni Zelanda cinsi tavşan (4-6 kg) iki guruba ayrıldı. Grup I kontrol grubu ( $n=7)$ olarak kullanılırken Grup II'ye ( $n=10)$ yüksek doz Tolüen verildi ( $876 \mathrm{mg} / \mathrm{kg} / \mathrm{ip})$. Üç saatlik deney periyodunun sonunda öldürülen hayvanlardan biyokimyasal analizler için kan serumu ve beyin doku örnekleri \% 10'luk nötral formaline alınıp parafine gömülerek kesildi $(5 \mu \mathrm{m})$. H\&E (hematoksilen-eozin), Crystal violet boyamaları, Na, K, GSH, MDA ve NO kan serum seviyeleri analiz edildi. Bu çalışma sonucunda Tolüen verilen tavşanlarda önemli ölçüde histopatolojik bozukluklar ve ciddi amiloit plak oluşumu gözlemlenmiştir. Tolüen grubunda Na, K, MDA, kan serumu seviyelerinde önemli ölçüde artış görülmüşken, GSH ve NO seviyelerinde anlamlı derecede azalma izlenmiştir. Bu çalışma sonucunda yüksek doz tolüenin beyin korteksinde akut dönemde ciddi hasarlar oluşturabileceği gösterilmiştir.
\end{abstract}

Anahtar sözcükler: Tolüen, oksidatif hasar, beyin korteksi, tavşan ve amyloid plak.

\section{Toxic Effects That Induced Acute Toluene Exposure In Rabbit Brain Cortex}

\begin{abstract}
This study aimed to investigate the histopathological and biochemical effect of high dose Toluene on brain cortex in acute period of Toluene treated rabbits. Seventeen adult female New Zealand rabbits (4-6 kg) were divided into two groups. Group I was used as a control group (n=7), while Group II was exposed to high dose of Toluene $(876 \mathrm{mg} / \mathrm{kg} /$ ip) $(n=10)$. After the 3 hours experimental period, blood serum for biochemistry analyses and brain tissues were taken from sacrificed animals and fixed in \% 10 neutral formalin, then, embedded in paraffin and sectioned (thickness, $5 \mu \mathrm{m}$ ). $\mathrm{H} \& \mathrm{E}$ (hematoxylin-eosin), Crystal violet dyes, Na, K, GSH, MDA and NO blood serum levels were analyzed. In this study, significant histopathological abnormalities and severe amyloid plaque formation was observed given the Toluene in rabbits. While $\mathrm{Na}, \mathrm{K}$, MDA blood serum levels significantly increase have been observed in the Toluene group, GSH and NO levels considerable have been decreased in the control group. As a result of this study showed that the high doses of Toluene in the cerebral cortex to cause serious damage in the acute phase.
\end{abstract}

Key words: Toluene, oxidative stress, brain cortex, rabbits and amyloid plaque.

\section{Giriş}

Tolüen özellikle boya ve kozmetik sanayinde yaygın olarak kullanılan, hoş kokulu, uçucu bir sıvı hidrokarbondur [16,21,30]. Tolüenin öfori yapıc1 etkisinden dolayı bağımlılı̆̆ına toplumda s1k rastlanılmaktadır. [6]. Ucuz ve kolay bulunabilir olduğundan dolayı bağımlıların tercihi sıklıkla tutkal ve tinerdir [32]. Özellikle boyacılar [37], ayakkabı işçileri [14,35], ve matbaa işçilerinde [19] mesleki maruziyet sık görülmektedir. Tolüen başlıca solunum, sindirim ve deri yoluyla vücuda alınabilir. Vücutta çoğunlukla iyi kanlanan ve yağdan zengin dokularda birikir $[1,5]$. Tutkal soluyarak ölen kişilerin karaciğer ve beyninde yüksek oranda tolüene rastlanmıştır. Vücuda alınan tolüenin büyük bir kısmı karaciğerde yıkılıp hippürik aside dönüştürülerek idrar yolu ile atılır [14]. Tolüen doz ve süreye bağlı olarak baş ağrısından ölüme kadar birçok klinik tabloya yol açabilir [5,30]. Yüksek dozda tolüene maruziyet genelde çalışanlarda ve bağımlılarda görülür $[16,35,37]$. Yüksek dozda meydana gelen zehirlenmeler üzerindeki araştırmalar daha çok akut entoksikasyon vakalarının değerlendirilmesine bağ11 çalışmalardır [4,34]. Tolüen sinir dokusunda daha fazla biriktiğinden çalışmalar daha çok sinir sistemi üzerine yoğunlaşmış ve uzun dönemde sinir sistemi üzerindeki kronik etkileri daha çok araştırılmıştır $[7,22]$. 
Yaptığımız bu çalışmada genelde kronik olarak maruz kalınan Tolüen'in beyin korteksi üzerine akut etkilerini histopatpolojik ve biyokimyasal metotlarla araştırmayı amaçladık. Tavşanlar üzerinde ve akut yüksek dozlarda bu konularda sınırlı sayıda çalışma bulunması bizim çalışmamızın önemini artırmaktadır. Toluen'in hem sanayide yoğun kullanılan bir madde olması hem de özellikle çocuk ve gençlerde olmak üzere kasıtlı ve özellikle intihar vakalarında sık kullanımı nedeniyle sağlık üzerine etkisi son derece önemlidir. $\mathrm{Bu}$ prensip doğrultusunda yapılan çalışmada Toulen kullanımına bağlı biyokimyasal dejenerasyonun ve histopatolojinin organizma sağlığı açısından önemli ve ciddi derecede değişiklikler gösterdiği belirtilmiştir.

$\mathrm{Bu}$ amaç doğrultusunda çalışmamızda, yüksek doz tolüenin tavşan beyin korteksi dokusunda akut dönemde meydana getirebileceği toksik etkilerin histopatolojik ve biyokimyasal olarak değerlendirilmesi amaçland.

\section{Materyal ve Metod}

Çalışmamız yerel etik kurul izni (HADYEK-51) alındıktan sonra Gaziosmanpaşa Üniversitesi Deneysel Tıp Araştırmaları Laboratuvarları'nda gerçekleştirildi. Hayvanlar Grup I kontrol grubu $(\mathrm{n}=7)$ ve Grup II Tolüen grubu $(\mathrm{n}=10)$ olarak tanzim edildi. Tolüen grubundaki deneklere tek doz $876 \mathrm{mg} / \mathrm{kg}$ intraperitoneal (ip) tolüen verildi. $\mathrm{Bu}$ doza önceki çalışmalardan esinlenerek karar verildi $[22,30]$. Deney hayvanları doz verildikten 3 saat sonra ketamin ve xylazin anestezisi altında bazal kan alınarak eksanguinasyon yöntemi ile öldürüldü. Alınan kanlar santrifüj edildikten sonra serumları ayrılarak - $80 \mathrm{C}^{\circ}$ 'de saklandı. Beyin dokuları çıkarılarak bouin solüsyonu içerisine alındı.

Deney hayvanlarından alınan beyin dokularının rutin doku takipleri yapılarak parafin bloklara gömülmesi sağlandıktan sonra bloklardan mikrotom ile $5 \mu \mathrm{m}$ kalınlığında kesitler alındı. Standart Hematoksilen\&Eozin boyaması gerçekleştirildi. Boyanan preperatlar Olympus BX-50 araştırma mikroskobunda incelendi. Deney hayvanlarından alınan kan serum numunelerinde $\mathrm{Na}, \mathrm{K}, \mathrm{MDA}$, GSH ve NO seviyelerinin tespiti için spektrofotometrik yöntemler ile ölçümler yapıldı.
Normallik denetimi Shapiro-Wilk testi ile gerçekleştirildi. Verilerin normal dağılıma uygun olduğu görüldü. İstatistiksel anlamlılık p $<0,05$ olarak kabul edildi. Grupların karşılaştırılmasında bağımsız iki örnek T testi kullanıldı.

\section{Bulgular}

\section{Klinik Bulgular}

Deneysel araştırmamızda Tolüen verdiğimiz tavşanlarda kontrol grubundan farklı bir şekilde makroskobik olarak pupillerde büyüme, kusma, bazı hayvanların ağız ve burun bölgelerinde kanama ve ayakta dengede duramama gibi postür bozuklukları gözlemlenmiştir.

\section{Biyokimyasal Bulgular}

Gruplara ait kan serum örneklerinde, spektrofotometrik olarak Na, K, NO, GSH ve MDA değerleri Tablo 1'deki gibidir. Buna göre oksidatif hasarı belirlemede önemli bir parametre ve kanda lipid peroksidasyonun bir göstergesi olan MDA düzeylerinin, tolüen uygulanan grupta istatistiksel olarak anlamlı bir şekilde arttığ tespit edildi $(\mathrm{p}<0,05)$. Antioksidan ve oksidatif hasarı düşürerek koruyucu ve düzenleyici etkisi olan NO ve GSH düzeylerinin kontrol grubuna kıyasla önemli ölçüde azaldığı bulundu $(\mathrm{p}<0,05)$. Tolüene maruz birakılan hayvanlarda serum $\mathrm{Na}$ ve $\mathrm{K}$ düzeylerinin kontrol grubuna oranla oldukça yüksek olduğu, bu yüksekliğin istatistiksel açıdan anlamlı olduğu belirlendi $(p<0,05)$.

Tablo 1. Tolüen ve kontrol grubu kan serum örneklerindeki Na, K, NO, GSH ve MDA değerleri

\begin{tabular}{|c|c|c|c|c|}
\hline & \multicolumn{2}{|c|}{ Grup } & \multirow[b]{3}{*}{$\mathbf{t}$} & \multirow[b]{3}{*}{$\mathbf{p}$} \\
\hline & Tolüen & Kontrol & & \\
\hline & $\overline{\mathbf{x}} \pm \mathbf{S H}$ & $\overline{\mathbf{x}} \pm$ SH & & \\
\hline $\mathbf{N O}(\mu \mathrm{mol} / \mathrm{L})$ & $4091,40 \pm 182,79$ & $5854,00 \pm 223,41$ & 17,880 & 0,001 \\
\hline $\operatorname{MDA}(\mu \mathrm{mol} / \mathrm{L})$ & $484,90 \pm 56,07$ & $345,86 \pm 42,10$ & 5,538 & 0,001 \\
\hline $\mathbf{N a}(\mathrm{mmol} / \mathrm{L})$ & $172,70 \pm 13,42$ & $139,29 \pm 3,82$ & 6,355 & 0,001 \\
\hline $\mathbf{K}(\mathrm{mmol} / \mathrm{L})$ & $678,70 \pm 64,76$ & $560,57 \pm 83,05$ & 3,300 & 0,005 \\
\hline $\mathbf{G S H}(\mu \mathrm{mol} / \mathrm{L})$ & $7791,20 \pm 630,26$ & $11403,00 \pm 887,00$ & 9,855 & 0,001 \\
\hline
\end{tabular}

Çalışmamızın biyokimyasal bölümünden elde ettiğimiz sonuçlara göre tolüen tavşanlarda oksidatif hasara yol açar ve vücut sıvısı elektrolit dengesini bozar (Tablo 1) $(\mathrm{p}<0,05)$. 


\section{Histopatolojik Bulgular}

Hematoksilen-Eozin ile boyanan preparatlar incelendiğinde, kontrol grubu beyin korteksi dokularının normal yapıda olduğu gözlendi (Şekil 1A). Tolüen verilen tavşanlarda ise beyin kortexinde fokal vakuoler dejenerasyon, gliozis, perivasküler demi- yelinizasyon, çok sayıda piknotik hücre ve nekroz alanları izlendi. Tolüen grubunda kontrol grubuna oranla belirgin derecede kan damarlarında aşırı genişlemeler ve hücreler arasındaki hücre hatların ciddi ölçüde dejenerasyona uğradığı hücre sınırlarının nerdeyse dağıldığ̣1 görülmektedir (Şekil 1B).
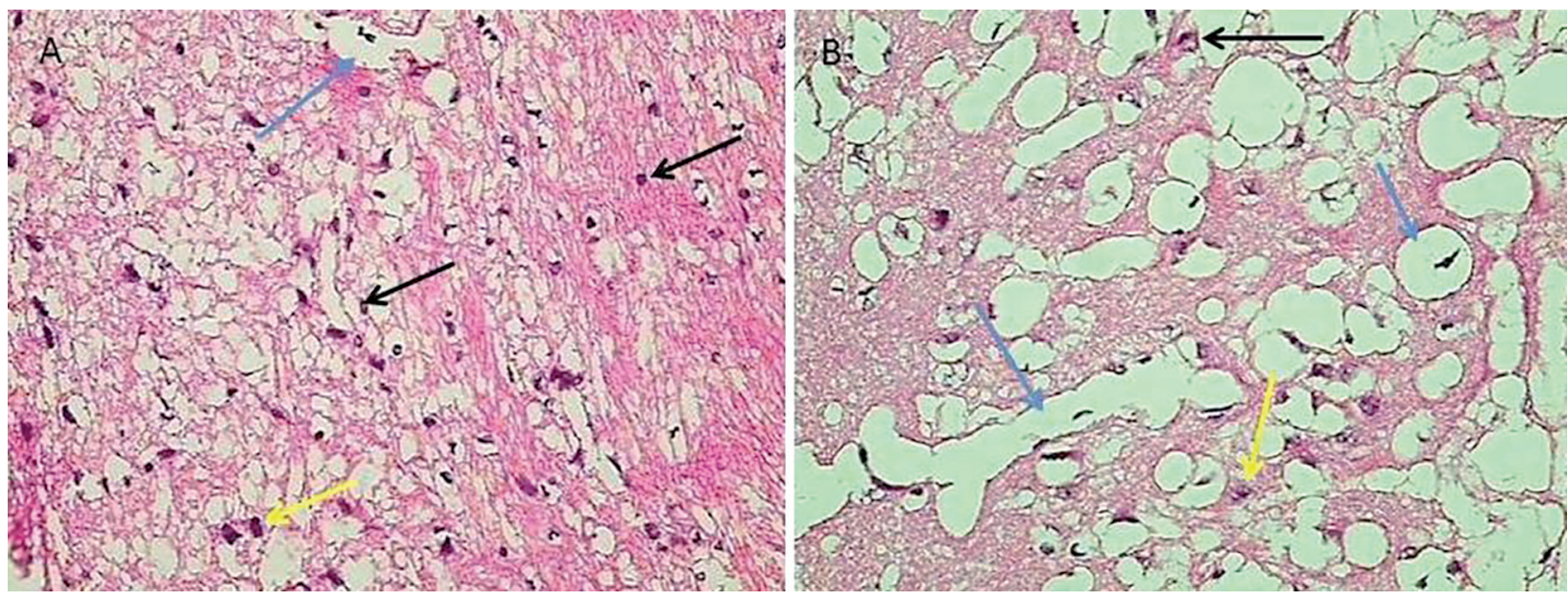

Şekil 1: Yüksek doz akut Toluen maruziyetine bağlı histopatolojik değişimlerin gösterimi H\&E boyama

*A) Kontrol grubu, beyin korteksi, H\&E (x40) B) Toluen grubu, beyin korteksi, H\&E (x40) (Oklarda gösterilen histomorfolojik değişiklikler; abseleşme(siyah ok), kan damarlarında hasar(mavi ok), gliozis ve hücre sınırlarında belirgin kayıplar(sarı ok))
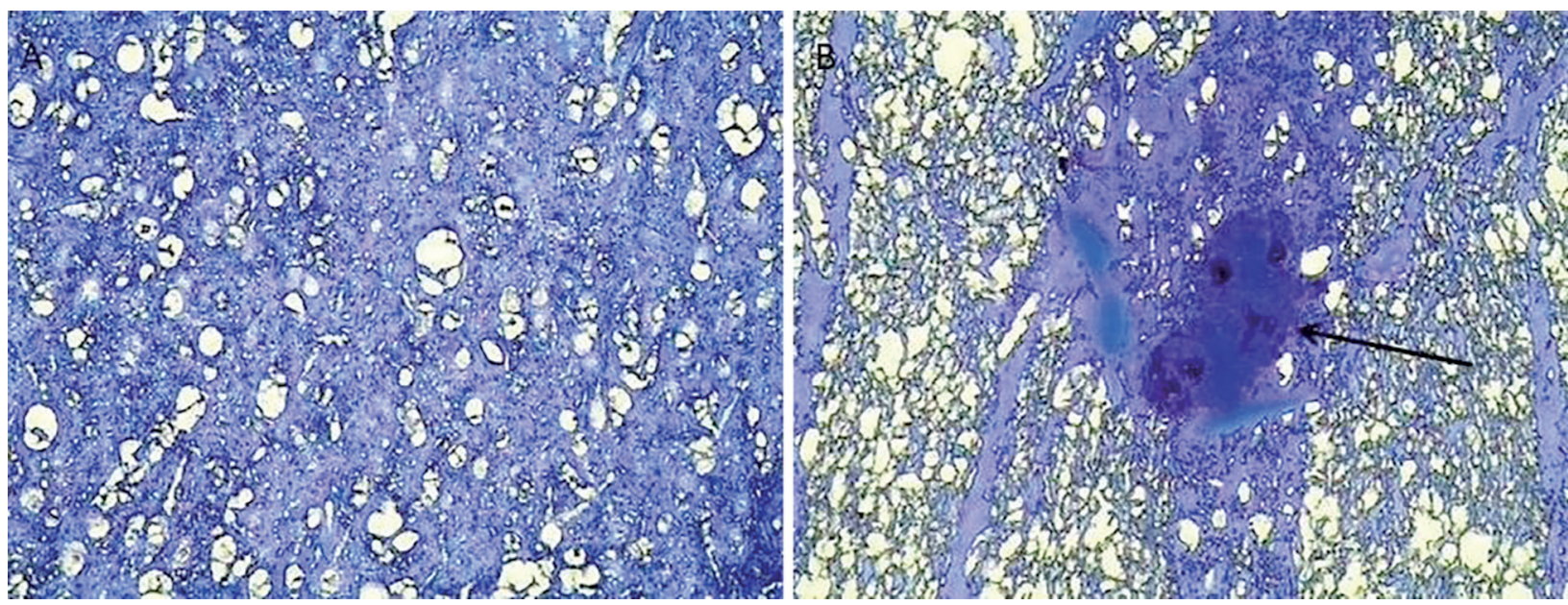

Şekil 2. Toluen maruziyeninin Kristal Viyolet boyanmasında senil ve amiloit plakların oluşumu 40X büyütme

*A) Kontrol Grubu Beyin Korteksi B) Toluen Grubu Beyin Korteksi

Kristal violet boyama yapılmış kesitler incelendiğinde kontrol grubunda spesifik bir boyanma gözlenmedi (Şekil 2A). Tolüen grubunda ki kesitler incelendiğinde ise boyanma yoğunluğunda belirgin bir artış olduğu ve Senil plakların büyüklüklerinin ve sayısının arttı̆g fark edildi. Nöronların hücre gövdelerinin ve uzantılarının etrafında amiloit plakların depolandığ 1 ve bu alanların genişleyerek senil plakları oluşturduğu gözlendi. Beyin korteksinin üst tabakasında daha az, alt tabakasında ise daha yoğun diffüz amiloit plak izlendi (Şekil 2B). 


\section{Tartışma ve Sonuç}

Tolüen hayatın birçok alanında kullanılan ve oldukça sık karşılașılan bir maddedir. Evde ve endüstride sayısız yerde kullanılması ile bağımlılık yapıcı bir madde olması ve istenildiğinde kolaylıkla temin edilebilmesi nedeniyle de popülasyonun önemli bir bölümünü etkileyen, diğer organik solventlerden farklı olarak özel bir öneme sahiptir [16,21,30]. Tolüenin özellikle santral sinir sistemi ve karaciğer başta olmak üzere birçok doku üzerinde toksik etkilerinin olduğunu kanıtlayan bir çok bilimsel araştırma bulunmaktadır [32]. Tolüene maruz kalan insan ve hayvanlarda ilk etki santral sinir sistemi depresyonudur. Yüksek konsantrasyonlarda diğer uçucu maddelerle benzer olarak psikomotor hasarlanma, lokomotor aktivitelerde eksitasyon ve daha sonrada inhibisyon, ayakta durma refleksinin kaybolmas ve sedasyon gibi etkileri vardır [14,35,37]. Tolüen bu etkileri gabaerjik, glutamaterjik, serotonerjik, dopaminerjik yolakları etkileyerek yapar $[6,8]$. Tolüen lipofilik özelliğinden dolayı hücre duvarındaki lipit yapısını değiştirir ve proteinlerle etkileşime girer. Akut dozlarda Na/K-ATPaz aktivitesini önemli oranda artırarak membran akışkanlığını artırır [9]. Deneysel araştırmamızda Tolüen verdiğimiz tavşanlarda 2-3 üncü saatler arasında hayvanlarda makroskobik olarak pupillerde büyüme, kusma, bazı hayvanların ağız ve burun bölgelerinde kanama ve ayakta dengede duramama gibi postür bozuklukları gözlemlenmiştir. Çalışmamızda serum sodyum ve potasyum değerlerinin kontrol grubuna kıyasla anlamlı derecede yüksek olduğu bulunmuştur.

Lipid peroksidasyonu, hücre zarındaki fosfolipidlerde bulunan çoklu doymamış yağ asitlerinin oksidasyonu ve bu nedenle hücre zarındaki lipid yapısında meydana gelen değişiklikler ile hücrenin yapısını ve fonksiyonlarının bozulmasıdır [36]. Serbest radikallerin zardaki doymamış yağ asitlerini etkileyerek bir kimyasal zincir tepkimesi ile başlayıp radikaller için devamlı bir kaynak oluşturarak hücre zarına geri dönüşümü olmayan bir hasar oluşturur [11,28]. Bir çok çalışmada, Tolüen maruziyetin doku, eritrosit ve plazma MDA seviyelerini arttırdığ 1 rapor edilmiştir [15, 20, 23, 38]. Çalışmamızda Tolüen grubunun MDA seviyeleri kontrol grubuna göre önemli ölçüde yüksek olduğu tespit edilmiştir. Bu sonuçlar reaktif oksijen türleri oluşumunun çok fazla olduğunu, serbest radikaller- le antioksidan savunma sistemi arasındaki dengenin bozularak oksidatif strese ve oksidatif hasara yol açtığını göstermektedir. Bu nedenle lipit peroksidasyonun en önemli ürünü olan MDA düzeylerinde artışa neden olduğunu düşündürmektedir.

Nitrik oksit suda ve yağda çözünebilen, organizmada vazoregulasyon ve hücresel toksisiteyi gösteren, kan ve endotel hücreleri arasında oluşan etkileşimin düzenlenmesinden sorumlu, antioksidan ve oksidatif hasarı azaltan biyolojik koruyucu ve düzenleyici bir moleküldür [25,26,31]. Çeşitli çalışmalarda, Tolüenin kan yoluyla tüm vücuda yayıldığ 1 ve dokularda birikerek serbest radikal oluşumunu arttırmış antioksidan seviyelerini ise azaltmışlardır [2,27]. Bizim çalışmamızda ise paralel bir şekilde Tolüene maruz bırakılan deneklerin plazma NO seviyeleri kontrol grubuna kıyasla anlamlı ölçüde azalma göstermiştir.

Glutatyon, tripeptit yapısında olan ve vücuttaki birçok hücrenin fonksiyonel proteinlerini oksidan maddelere karşı koruyan bir moleküldür [10]. Glutatyon DNA'nın sentezinde, hasarlı parçalarının onarılmasında, metabolik fonksiyonların yerine getirilmesinde, zehirli maddelerin inaktif hale dönüştürülmesinde ve serbest radikallerin muhtemel hasarlarının önlenmesinde görev yapmaktadır [12]. Park ve ark. (2006) çalışmalarında organik çözücü ve sigaraya maruz kalan bir vücutta serbest radikal ve reaktif oksijen türlerinin artarak kanser gibi hastalıklara sebep olduklarını, glutatyon gibi antioksidan maddelerinde vücut dokularında biriken bu serbest radikallere karşı koyarak toksik olan bu maddeleri zararsız hale getirdiklerini ve bu yüzden antioksidanların konsantrasyonlarında azalma meydana geldiğini göstermişledir [33,34]. Çalışmamızda da, elde ettiğimiz Tolüen grubunun serum glutatyon miktarının kontrol grubuna göre anlamlı ölçüde azalmış olması bu duruma paralellik göstermektedir. Ayrıca süperoksit radikalinden daha zayıf etkili olan hidrojen peroksit, dokularda bulunan glutatyon enzimi ile su ve oksijen gibi daha zayıf etkili ürünlere dönüştürülerek etkisiz hale getirilmesi gerekirken glutatyon konsantrasyonlarında ki bu azalma oksidatif hasara neden olduğunu düşündürmektedir.

Araştırmamızda yapmış olduğumuz hematoksilen-eozin boyamaları sonucunda, kontrol grubu beyin korteksi dokularının normal yapıda olduğu gözlenmektedir. Tolüen verilen tavşanlarda beyin 
kortexinde fokal vakuoler dejenerasyon, gliozis, perivasküler demiyelinizasyon, çok sayıda piknotik hücre ve nekroz alanları izlenmektedir. Tolüen grubunda kontrol grubuna oranla kan damarlarında aşırı genişlemeler ve hücreler arasında kompenzasyonun ciddi ölçüde dejenerasyona uğradığı hücre sınırlarının nerdeyse tamaen gözden silindiği görülmektedir.

Senil plaklar; dejenere nöronal uzantılar, reaktif glial hücreler ve peptidlerden meydana gelen komplike lezyonlardır. Başlangıçta nöron gövdeleri ve uzantıları etrafında diffüz amiloit birikir. Ardından bu maddelerin birikimi yoğunlaşarak ve genişleyerek senil plakları oluşturur [3]. Çalışmamızda tolüen verilen grupta amiloit proteinlerinin senil plaklarda belirgin şekilde biriktiğini göstermektedir. Histokimyasal olarak tolüen verilen grupta amiloit proteinlerinin birikimine bağlı olarak boyanma yoğunluğu ve boyanan alanların büyüklüğünde ve sayısında artış olmaktadır. Amyloid plak oluşumu Alzheimer hastalığının ilk patolojik olayı olup nöritik plak oluşumuyla sonuçlanabilmektedir. Amyloid plaklar serebrumda bulunan arteriollerde birikerek amyloid anjiopati oluşturmaktadır. Alzheimer hastalarında serebrumda bulunan meningeal arteriollerde amyloid plak gözlemlenmiştir [17,18,29].

Amiloit birikiminin Alzheimer' a neden olabileceği konusunda yapılan bir çalışma da amiloit birikimi olan nöronal uzantılarda meydana gelen morfolojik değişiklikler ile aksiyon potansiyellerinin ve bu nedenle iletimin geciktiği bildirilmiştir [24]. Dickson (1997) bir araştırmasında korteksin üst tabakasında daha az diffüz yoğunluk ancak alt korteks tabakasında ise daha fazla diffüz yoğunluk olduğunu rapor etmiştir [13]. Yaptığımız çalışmada tolüen grubunda bu duruma paralel bir şekilde beyin korteksinin üst tabakasında daha az korteksin alt katmanlarında daha yoğun diffüz amiloit plak oluşumu görülmüşür. Kontrol grubunda ise boyanma yoğunluklarında herhangi bir değişiklik gözlemlenmiştir. Bu durumda tolüen maruziyetinin senil plakların oluşumunu arttırarak alzheimera neden olma olasılığını artırabileceğini düşünmekteyiz.

\section{Sonuç}

Sonuç olarak yüksek dozda tolüenin 3 saat gibi çok kısa bir sürede bile önemli beyin hasarı oluşturdu- $\breve{g u}$, senil amiloit plak oluşumu ve serum antioksidan seviyelerinde önemli derecede azalmanın meydana getirmesi ile akut tolüen maruziyetinin vücutta kalıcı ve geri dönüşümü zor hasarlar oluşturmasının mümkün olabileceği kanaatine varıldı.

\section{Aknowledgments (Teșekkür)}

Çalışmamız Atatürk Üniversitesi BAP 2014/183 nolu proje tarafından desteklenmiştir.

\section{Kaynaklar}

1. Agency for Toxic Substances and Disease Registry (ATSDR), (2000). Toxicological Profile for Tolüene. http:// www.atsdr.cdc.gov/toxprofiles/tp56.pdf. Erişim tarihi: 25.10.2016.

2. Altındag A, Ozkan M, Oto R, (2001). Inhalanla ilişkili bozukluklar. Klinik Psikofarmokoloji Bülteni. 11:143-148.

3. Arends YM, Duyckaerts C, Rozemuller JM, Eikelenboom P, Hauw JJ, (2000). Microglia, amyloid and dementia in alzheimer disease. A correlative study. Neurobiol Aging. 21:39-47.

4.Argo A, Bongiorno D, Bonifacio A, Pernice V, Liotta R, Indelicato S, Zerbo S, Fleres P, Ceraulo L, Procaccianti P, (2010). A fatal case of a paint thinner ingestion: comparison between toxicological and histological findings. Am J Forensic Med Pathol. Jun;31(2), 186-91.

5. ATSDR (Agency for Toxic Substances and Disease Registry), (2006). Case Studies in Environmental Medicine. Tolüene Toxicity. http://www.atsdr.cdc.gov/csem/Tolüene/. Erişim tarihi: 25.10.2016.

6. Balster RL, (1998). Neural basis of inhalant abuse. Drug Alcohol Depend. 51,207-14.

7. Baydas G, Reiter RJ, ve ark., (2003). Melatonin protects the central nervous system of rats against Tolüene-containing thinner intoxication by reducing reactive gliosis. Toxicol Lett. 137, 169-174.

8. Bowen SE, Batis JC, Mohammadi MH, Hannigan JH, (2005). Abuse pattern of gestational Tolüene exposure and early postnatal development in rats. Neurotoxicol Teratol. 27, 105-116.

9. Calderon-Guzman D, Espitia-Vazquez I, Lopez-Dominguez A, Hernandez-Garcia E, Huerta-Gertrudis B, CoballaseUrritia E, ve ark., (2005). Effect of Tolüene and nutritional status on serotonin, lipid peroxidation levels and $N A+/ K+-$ ATPase in adult rat brain. Neurochem Res. 30, 619-624.

10. Champe PC, Harvey RA, (1997). Glikozaminoglikanlar. Tokullugil A, Dirican M, Ulukaya E,. Lippincott's illustrated reviews serisinden: Biyokimya. İkinci bask1, Nobel Tip Kitabevi, İstanbul. p. 147-156.

11. Canoruç N, Çiçek R, Atamer A, Dursun M, Turgut C, Güneli E, Canoruç F, (2001). Protective effects of vitamin $E$ selenium and allopurinol against stres-induced ulcer formation in rats. Turk J med Sci. 31,199-203. 
12. Chavan S, Sava L, Saxena V, Pillai S, Sontakke A, Ingole $\mathrm{D},(2005)$. Reduced glutathione: Importance of specimen collection. Indian Journal of Clinical Biochemistry. 20(1), 150-152.

13. Dickson DW, (1997). The pathogenesis of senile plaques. $\mathrm{J}$ Neuropath Exp. Neurol. 56, 321-339.

14. Dossing, M, Aelum, JB, Hansen, SH, Lundqvist, GR, Andersen, NT, (1983). Urinary hippuric acid and orthocresol excretion in man during experimental exposure to Tolüene. Br J Ind Med. 40, 470-473.

15. Dündaröz MR, Turkbay T, Akay C, Sarıcı SU, Aydın A, Denli M, Gökçay E, (2003). Antioxidant enzymes and lipid peroxidation in adolescent with inhalant abuse. Turk $\mathrm{J}$ Pediatr. 45(1),43-45.

16. Faust RA, (1994). Toxicity Summary for Tolüene. OAK Ridge Reservation Enviromental Restoration Program. Chemical Hazard Evaluation Group Biomedical and Environmental Information Analysis Section Healt Sciences Research Division. http://riskassessment.ornl. gov/documents/Tolüene.pdf. Erişim tarihi: 25.10.2016.

17. Georganopoulou DG, Chang L, Nam JM, ve ark., (2005). Nanoparticle-based detection in cerebral spinal fluid of a soluble pathogenic biomarker for Alzheimer's disease. Proc Natl Acad Sci USA. 102, 2273.

18. Gong Y, Chang L, Viola KL, ve ark., (2003). Alzheimer's Disease affected brain: presence of oligomeric A beta ligands (ADDLs) suggests a molecular basis for reversible memoory loss. Proc Natl Acad Sci USA. 100, 10417.

19. Guzelian P, Mills S, Fallon HJ, (1988). Liver structure and function in print workers exposed to Tolüene. J Occup Med. 30, 791-796.

20. Ilgazlı A, Şengül C, Maral H, Özden M, Erçin C, (2004). The effects of thinner inhalation on superoxide dismutase activities, malondialdehyde and glutathione levels in rat lungs. Clin Chim Acta. 343(1-2),141-4.

21. Jones HE, (1997). Neurobehavioral consequences of intermittent prenatal exposure to high consentrations of Tolüene. Neurotoxicology and Teratology. 4, 305-13.

22. Kanter M, (2011). Protective effects of thymoquinone on the neuronal injury in frontal cortex after chronic Tolüene exposure. J Mol Histol. 42(1), 39-46.

23. Karagözler AA, Mehmet N, Batçığlu K, (2002). Effects of long-term exposure on blood cytokine levels and antioxidant enzyme activities in house painters. J Toxicol Environ Health A. 65(17), 1237-46.

24. Knowles RB, Wyart C, Buldyrev SV, Cruz L, Urbanc B, Hasselmo ME, Stanley HE, Hyman BT, (1999). Plaqueinduced neurite abnormalities: implications for disruption of neural networks in Alzheimer's disease. Proc Natl Acad Sci U S A. 96,5274-5279.
25. Kuyumcu A, Duzgun AP, Ozmen MM, Besler HT, (2004). Travma ve enfeksiyonda nitrik oksidin rolü. Ulus Travma Dergisi. 10(3),149-159.

26. Matthew BG, Jourd'heuil D, Wink DA, (1999). Nitric oxide I. Physiological chemistry of nitric oxide and its metabolites: implications in inflammation. Am. J. Physiol. 276,315-321.

27. Mohan IK, Dsa UN, (1997). Oxidant stress, antioxidants and essential fatty acids in bronchial asthma. Med. Sci. Res. 25,307-309.

28. Murray RK, Granner DK, Mayes RA, Rodwell VW, (1996). Fizyolojik öneme sahip lipidler. Dikmen N, Özgünen T, Harper'ın Biyokimyası, Yirmidördüncü baskı, Barış Kitabevi, İstanbul.

29. Naslund J, Haroutunian V, Mohs R, ve ark., (2000). Correlation between elevated levels of amyloid beta-peptide in the brain and cognitive decline. JAMA. 283, 1571.

30. OEHHA (Office of Environmental Health Hazard Assessment), (1999). Public Health Goal for Tolüene in Drinking Water. http://oehha.ca.gov/water/phg/pdf/ tolu f.pdf. Erişim tarihi: 20.10.2016.

31. Palmer RMJ, Ferrige AG, Moncada S, (1993). Nitric oxide release accounts fort he biological activity of endotheliumderived relaxing factor. Nature. 327,524-6.

32. Park CK, Kwon KT, Lee DS, Jo CM, Tak WY, Kweon YO, ve ark., (2003). A case of toxic hepatitis induced by habitual glue sniffing. Korean J Hepatol. 4, 332-336.

33. Park E, Park Y, Gwak Y, (1998). Oxidative damage in tissues of rats exposed to cigarette smoke. Free Radical Biology \& Medicine. 25(1),79-86.

34. Park JJ, Chang H, Jung JY, Jung SJ, Song KH, Suh WN, ve ark., (2006). A Case of Tolüene-induced Renal Tubular Acidosis Presented with Hypokalemic Paralysis. www.jksem.org. 17(6), 656-658.

35. Tomei F, Giuntoli P, Biagi M, Baccolo TP, Tomao E, Rosati MV, (1999). Liver damage among shoe repairers. Am J Ind Med. 36, 541-547.

36. Thomas JA, (1999). Including glutathione, a peptide for cellular defense against oxidative stress. Free Radical Biology and Medicine. 27,916-921.

37. Tsatsakis AM, Dolapsakis G, Troulakis G, Christodoulou P, Relakis K, Trikilis N, ve ark., (1997). Fatal and nonfatal outcome by accidental intoxication with paint thinner. J Clin Forensic Med. 4, 133-137.

38. Ulakoğlu EZ, Sayg1 A, Gümüștüş MK, Zor E, Öztek İ, Kökoğlu E, (1998). Alterations in superoxide dismutase, lipid peroxidation and glutathione levels in thinner inhaled rat lungs: Relationship between histopathological properties. Pharmacological Research. 38(3),209-214. 